the ether, and they are taken up again by matter. One kind of wave gives us light, another radiant heat, another magnetism, and another electrification. The rate at which these waves move is the same, viz. $30,000,000,000$ centimetres, or 192,000 miles, per second. It is only their, form and their frequency that differ. Matter and ether are subject to strains, currents, vortices, and undulations, and every single electro-magnetic phenomenon can be compounded of or reduced to one or other of these mechanical disturbances. Rotation in one direction gives positive electrification : rotation in the opposite direction gives negative electrification. A whirl in one direction gives us north magnetism; in another direction, south magnetism. Hertz, the experimental exponent of Maxwell's views, has shown the existence of electro-magnetic waves, and has proved their reflection, refraction, and interference. The rate of their propagation is the same in ether, air, and conducting wires.

The most recent discoveries and deductions are all in accordance with this mechanical theory. J. J. Thomson's views that at high temperatures, in the act of dissociation, all gases, and Dewar and Fleming's conclusion that at low temperatures-in fact, at the absolute zero of temperature-all metals become perfect conductors, might almost have been predicted. Hysteresis and Foucault losses are mere wastes of energy, due to molecular friction or to internal work done on the molecules, assisted by bad design and impure material; but, being measurable and comprehensible, their reduction to a minimum has become possible and actual.

It is a misfortune that a beautiful hypothesis like Maxwell's electro-magnetic theory of light has been discussed almost solely by mathematicians. Its consideration has been confined to a small and exclusive class. It has not reached the public; and this is to be regretted, for, after all, it is the many, and not the few, that determine the acceptance or refusal of a theory. The existence of the ether is now thoroughly comprehensible. Light is now regarded as an electro-magnetic disturbance. The eye is an extremely sensitive and delicate electro-magnetic instrument. The difference between luminous, thermic, and electro-magnetic waves is one of frequency and form. We thus have to consider the propagation of these waves not only in the conductor and in the dielectric in the direction of the circuit itself, but in the ether at right angles to this direction. The former produces currents in the conductor, and the latter induction and secondary effects in contiguous conductors. Thus it is easy to see why electric and magnetic lines of force are at right angles to each other, and each of them perpendicular to the line of propagation of the primary electro-magnetic wave, and why the transversal disturbances are secondary waves of electro-magnetic energy which can be transformed into electric currents of opposite direction whenever contiguous conductors lie in their path so as to be cut by these lines of force in the proper direction. Induction is thus mere transformation of energy whose direction and magnitude are easily calculated.

It is by following out this line of thought that I have recently succeeded in sending messages by Morse signals across the Bristol Channel between Lavernock and Flat Holm, a distance of $3 \mathrm{I}$ miles. The electro-magnetic disturbances were excited by primary alternating currents in a copper wire, 1237 yards long, erected on poles along the top of the cliff on the mainland. The radiant electro-magnetic energy was transformed into currents auain in a secondary circuit, 6 ro yards long, laid along the island. The strength of these secondary induced currents complied almost exactly with calculations. The results attained, the apparatus used, the precautions taken to separate effects of induction from effects of conduction ; the elimination of mere earth currents from electromagnetic disturbances in air, will form the subject of a separate paper, for their proper consideration would be too tedious for an address. I allude to them now only to illustrate the existence of one of the greatest proofs of the truth of a theory, viz. the practical develupment and verification of a conclusion predicted from mere theoretical considerations.

The o-cillatory character of the discharge of a Leyden jar, which was discovered by Henry in 1842 , is an admirable proof of this molecular theory. It two jars, precisely similar as regards capacity and circuit inertia, be placed near each other with their planes parallel, and one of them is charged and discharged, the other responds sympatheticaily, as do two similarly pitched tuning-forks when one is excited. Professor Oliver Lodge, who has made this field his own, has shown that by varying the capacity of the jars and the inertia of the circuit, oscillations can be produced to give any required rate of oscillation from one to 300 millions per second.

In a room or theatre, when these discharges are excited, it is a common thing to see sympathetic sparks upon the spangled walls, and among the metallic objects scattered about. The whole place is an electric field, which is violently disturbed at every spark, and everything which is "syntonised," as Oliver Lodge calls it, to the main discharge, responds in this way.

It is impossible to account for these effects, which are all cases of transformed kinetic energy, except on the mechanical theory which I have advanced. We have a source of disturbance, we have energy transmitted in waves, we have wave transformed into disturbance again. Energy passes through its various stages by the motion of matter and the action of the ether. Everything is accounted for and nothing is lost. Waste energy only means energy in the wrong place.

\section{YEZO AND THE AINU.}

TWO papers on recent travels in the Island of Yezo were read to the Royal Geographical Society on Monday evening. Prof. J. Milne, F. R.S., whose paper was read by the Secretary, made a journey to the north-east of the island by sea in $189 \mathrm{I}$, and returned by land, crossing Yezo almost through its centre. $\mathrm{He}$ was accompanied by Mr. John Revilliod, and travelled with a view to studying the volcanic geology of the regions. Landing at Kushiro, interesting on account of the relics of pre-Ainu inhabit. ants, and on account of its coal mines, they ascended the Kusuri river to Shibecha, where there is a great convict prison and sulphur refinery, the raw sulphur being obtained from the volcano Atosanobori, to which there is a railway twenty miles long. In this locality the violence of the escape of steam from the boiling springs exceeds anything seen elsewhere in Japan, New Zealand, or Iceland. A new road, thirly-seven miles long, led from the volcano to Apashiri, on the north-east coast, where a factory for making matches has recently been erected, on account of the abundance of the white-stemmed poplar, the timber of which is much more readily worked in the fresh state than when dried. A boat journey was made in a small dug -out canoe under rugged cliffs from 500 feet to 1000 feet in height, for thirty miles to Shiritoki, where there is a great sulphur mine. From some of the volcanic craters fused sulphur flows like lava, and crystallises in an almost pure state. A trip from Nemuro to the nearer Kurile Islands was followed by the main feature of the journey, a ride from Yubets, on the north coast, up the Yubets river, across the watershed, and down the Ishikari river, to the west coast. Groups of convicts working on the new roads, which are being made across the island, were almost the only people met with. Vast groves of tall bamboo grass everywhere impeded the travellers, and insects of all kinds proved very troublesome. There was little or no sign of larger animal life.

Mr. A. H. Savage Landor also read a paper. He had wandered all round Yezo and up several of the largest rivers quite alone, and with no object save curiosity and the desire to study the Ainu at home. The main part of his equipment was a great store of painting material, of which he made good use in portraying both the natives and the scenery of the island. The Ainu accessible from Hakodate, who have been frequently visited and often described, are almost all Japanese half-breeds, and much influenced in customs and costume by their southern neighbours. The Ainu of the interior and the more distant parts of the coast were very different. The true Ainu villages are intensely filthy, and the vermin in them make life almost unsupportable to a stranger, minute black flies, which swarm in incredible hosts, being the worst. The people, although goodhumoured, are sunk in the most degraded savagery. Their marriage customs seem to be summed up in unqualified promiscuity, the Ainu disclaiming any idea of being better than bears or dogs. The Ainu language is poor in words, and many of them sho:v a curious resemblance to words of AngloSaxon origin, e.g. Chip, for ship ; Do, day ; Mukku, music; Pone, bone ; Ru, road ; To, two ; Wakka, water. The religious beliefs of the Ainu can hardly be dignified by such a term; they are merely superstitions. In travelling along the south-west coast there was often considerable danger from the waves washing over the narrow track which wound between the boulders on the beach. Fog prevails along the east coast in summer, probably on account of the Kuro-Siwo encountering a cold current off the island. The upper Tokachi river was the 
most remote part of Yezo visited, a region which had scarcely been traversed by the Japanese. Here the Ainu were found to be more hairy than elsewhere, and to present many Aryan features in their general appearance. One peculiar fact brought out by many measurements was the remarkable length of their arms. The measurement across the outstretched arms is always from three to five inches more than the height of the individual. The future capital of Hokkaido (the name given to Yezo and the Kurile Islands collectively) is to be erected on the Kamikawa plain, in the very centre of Yezo, and roads are being pushed forward to connect it with all parts of the coast. It will, when completed, take the place of the present capital, Sapporo. According to Japanese mip;, Mr. Landor's journey extended to 5000 miles, but his own reckoning puts it as 3800 ; almost the whole distance was done on horseback.

\section{UNIVERSITY AND EDUCATIONAL INTELLIGENCE}

OXford. - By the death of Prof. Westwood on January 2 the University lost one of the most learned of its members, and another link with the earlier study of science in Oxford is gone. Prof. Westwood became Hope Professor on the foundation of the chair by the Rev. F. W. Hope in 1861 , and afterwards devoted his time to the perfecting of the collection which $\mathrm{Mr}$. Hope bestowed on the University. The collection, which has received considerable additions from other sources, including the Burchell collection, Wallace's types, \&c., has attained somewhat unmanageable proportions, and its present quarters are too small for its proper display. Whoever succeeds to the chair, it is to be hoped that suitable provision will be afforded to enable him to make the collection of more use to University studies than has hitherto been the case.

In November last an examination for a Radcliffe Travelling Fellowship, thrown open, pro hac vice, to all branches of natural science, was held, but the result has not yet been announced. It is now announced that an examination will be held during this term for a second Radcliffe Fellowship, the subjects being strictly medical. It is believed that the results of the two examinations will be published together at the end of this term. There is some dissatisfaction at the delay in announcing the result of the first examination.

Prof. Ray Lankester has recovered from the illness which necessitated his absence from Oxford last term, and has resumed his lectures on the Vertebrata and a senior course on the Arachnida.

The Mathematical Scholarships and Exhibitions bave been awarded as follows :-

Senior Mathematical Scholar, R. C. Fowler, B.A., of New College.

Proxime Accessit, S. F. White, B. A., of Wadham College, to whom the Examiners have awarded Lady Herschell's book.

Junior Mathematical Scholar, C. B. Underhill, Balliol College.

Junior Mathematical Exhibition, J. F. McKean, Hertford College.

Proxime Accessit, W. C. Childs, Corpus Christi College.

The Duchess of Marlborough has bestowed on the Chemical Department the entire collection of chemical and electrical apparatus belonging to the late Duke. The collection, which includes two exceptionally fine spectroscopes, delicate balances, $\& c$, has been brought to the Museum from Blenheim, and forms a valuable addition to the Chemical Laboratory.

Mr. E. L. Collis, of Keble, is President, and Mr. M. D. Hill, of New College, is Treasurer of the. Junior Scientific Club this term, and Messrs. C. H. H. Walker, of University College, and T. H. Butler, of Corpus Christi, are respectively Chemical and Biological Secretaries. The first meeting is held on Wednesday, February I, when Mr. J. E. Marsh exhibits some products of the electrical furnace, and Messrs. Finn and Fremantle read papers on East Africa and Hermaphroditism.

At a meeting of the Biological Club, on Saturday last, Mr. $G$. C. Bourne read a paper on the influence of the nucleus on the cell.

CAMBrIDge. - The Senate have resolved to appoint a Demonstrator in Palæozoology in connection with the Geological Department. He will have no stipend from the University, but will be remunerated from the fees paid by students.

NO. 12 I4, VOL. 47 ]
Dr. Allbutt, Regius Professor of Physic, Dr. A. MacAlister, Professor of Anatomy, and Dr..Donald MacAlister, University Lecturer in Medicine, have been appointed to represent the University at the Eleventh International Medical Congress to be held at Rome in September next.

Dr. W. H. Gaskell has been appointed a member of the Special Board for Medicine, and Mr. C. T. Heycock a member of the Special Board for Physics and Chemistry. Dr. Ransome, F.R.S., Honorary Fellow of Gonville and Caius College ; Dr. Corfield, F.R.S, Professor of Hygiene and Public Health in University College, London; Dr. J. Lane Notter, Professor of Military Hygiene at Netley; and Dr. Thorne Thorne, F.R.S., Medical Officer to H.M. Local Government Board, have been appointed Examiners in State Medicine for the Diploma in Public Health during the current year.

Sir G. G. Stokes and Dr. Hobson have been elected Examiners for the Adams Memorial Prize to be awarded in 1895 .

Mr. E. H. Acton, of St. John's, and Mr. T. H. Eastertield, of Clare, have been approved as Teachers of Chemistry with reference to the regulations for medical and surgical degrees.

\section{SOCIETIES ANID ACADEMIES.}

\section{LONDON.}

Royal Society, December 15, 1892.- "Experiments on the Action of Light on Bacillus anthracis." By Prof. Marshall Ward, F.R.S.

It is abundantly evinced by experiments that direct insolation in some way leads to the destruction of spores of Bacillus anthracis, and in so far the results merely confirm what had already been discovered by Downes and Blunt in 1877 and I $878 .^{1}$

From the fact that an apparent retardation of the development of the colonies on plates exposed to light was observed several times under circumstances which suggested a direct inhibitory action of even ordinary daylight, the author went further into this particular question with results as startling as they are important, for if the explanation given of the phenomena observed in the following experiments turns out to be the correct one, we stand face to face with the fact that by far the most potent factor in the purification of the air and rivers of bacteria is the sunlight. The fact that direct sunlight is efficacious as a bactericide has been long suspected, but put forward very vaguely in most cases.

Starting from the observation that a test-tube, or small flask containing a few c.c of Thames water with many hundreds of thousands of anthrax spores in it may be entirely rid of living spores by continued exposure daily for a few days to the light of the sun, and that even a few weeks of bright summer daylight -not direct insolation-reduces the number of spores capable of development on gelatine, it seemed worth while to try the effect of direct insolation on plate-cultures to see if the results could be got more quickly and definitely. ${ }^{2}$

Preliminary trials with gelatine plate-cultures at the end of the summer soon showed that precautions of several kinds were necessary. The direct exposure of an ordinary plate-culture to the full light of even a September or October sun, especially in the afternoon, usually leads at once to the running and liquefastion of the gelatine, and although the exposed plates eventually showed fewer anthrax colonies than similar plates not exposed, the matter was too complicated to give satisfactory results. Obviously one objection was that the spores might have begun to germinate, and the young colonies killed by the high temperatures.

Experiments made in October with gelatine plates wrapped in black paper, in which a figure-a square, cross, or letter - was cut, also led to results too indefinite for satisfaction, although it was clear in some cases that if the plates lay quite flat, the illuminated area was on the whole clear of colonies, while that part of the plate covered by the paper was full of colonies.

But another source of vexation arose. After the plates had been exposed to the sunlight for, say, six hours, it was necessary to put them in the incubator $\left(20^{\circ}-22^{\circ} \mathrm{C}\right.$. was the temperature used) for two days or so, to develop the colonies, and in many cases it was observed that by the time the colonies were sufficiently

x See p. 237 of "First Report to the Water Research Committee of the Royal Society" (" Roy. Soc. Proc." col. 51, 1892) for the literature on this subject up to 189 .

2 It appears that Buchner (Centr, f Balct. vol. xii. 1892 ) has already done this for typhoid, and finds the direct rays of the su inmer sun quite effective. 